\title{
接合コストを考慮した自由曲面鋼構造の形状・断面最適化 SHAPE AND SECTION OPTIMIZATION FOR FREE-FORM STEEL STRUCTURES CONSIDERING CONNECTION COST
}

\author{
藤井英二*, 荒木慶一**, 上谷宏二*** \\ Eiji FUJII, Yoshikazu ARAKI and Koji UETANI
}

\begin{abstract}
A shape and section optimization method is presented for free-form steel structures considering cost of connections. Two types of rigid connections are considered. One is a conventional full-strength connection, and the other is a partial-strength connection using for example fiber reinforced mortar. The inherently different costs of the two are made continuous by introducing a cost increase function of the latter. A nest-structure optimization, consisting of a shape and section optimization as the main problem and cost minimization of each connection as the sub-problem, is proposed to minimize the total cost of members and connections. Examples of a single-layer lattice roof are shown to demonstrate the effectiveness of the proposed method.
\end{abstract}

\author{
Keywords : Shape and section optimization, Free-form steel structures, Connection cost, Fiber-reinforced \\ mortar \\ 形状・断面最適化，自由曲面鋼構造，接合コスト，䋊維補強モルタル
}

\section{1. 序論}

近年, 幾何学的な規則性を持たない曲面, いわゆる自由曲面を屋 根やファサードに用いた建築物が増加している。こうした建築物の 多くが鋼構造の単層ラチス形式をとっているが，そこでは鋼材量は もちろんのこと，接合部の製作性が鉄骨工事費に大きな影響を与え る。コストは様々な要因によって決定されるため一概に論じること はできないが，接合部に関連するコストが鉄骨工事費の $3 \sim 4$ 割を 占めることも珍しくない。これは, 多様な角度で取り合う鉄骨部材 を十分な強度と岡性をもって接合するために, 3 次元 $\mathrm{CAD} / \mathrm{CAM}$ を 駆使した複雑な溶接組立や，鋳鋼ノード，切削加工ノード等(以下, まとめて任意角 $\mathrm{S}$ 接合と呼ぶ), 一般に高コストの解決策を採らざる を得ないことによる。

こうした自由曲面が建築設計者(意匠設計者)から提示された場合， 構造設計者は, 球面等の幾何学的な規則性を持つ曲面で自由曲面を 近似して接合部を標準化したり, 逆に半剛接合や部分強度接合を採 り入れて接合部を簡素化したりすることで, 総合的な合理化を模索 することとなる。部材や接合部のコスト, 形状, 構造性能等の間に は相関があり，しばしばトレードオフ関係にあるため, こうした場 合には架構(形状，部材配置，部材断面)と接合部を統合的に捉える ことが必要である。しかしながら現実の構造設計では, 形状および 部材配置, 部材断面, 接合部の順に, それぞれの段階で最善の策を
講じながら設計が進められることが多い。

架構と接合部を統合的に取り扱った最適設計手法は多く提案され ている。例えば大崎 ${ }^{11}$ は，接合コストを考慮したトラスのトポロジ 一最適化問題を遺伝的アルゴリズム $(\mathrm{GA})$ を用いて解く手法を示し ている。接合コストは節点に接合される部材が存在しない場合に 0 とされる。しかしながら，ある空間を覆う形で用いられることが多 い自由曲面鋼構造において, 節点の消滅ひいては架設領域の減少を 伴うようなトポロジー最適化を適用することは難しい。松本ら 2)は, 部材端の接合剛性を表すパラメータ(接合係数) と部材コストとの関 係を仮定した上で，部材断面積と接合係数を設計変数として総部材 コストを最小化する手法を提案している。しかしながら，求められ た最適接合剛性を実際の架構で精度良く実現することは困難である。 清水ら ${ }^{3)}$ ，佐々木ら 4)は，接合部の溶接等にかかる製作コストを実 物件データに基づいて評価した上で，材料コストと製作コストの和 を最小化する最適設計問題を示している。これは基本的に整形骨組 を対象とした手法であり，任意角 $\mathrm{S}$ 接合を用いる自由曲面鋼構造に 適用することは難しい。なお，繊維補強セメント複合材料を用いた 簡易な接合構法が多く提案されており 5) 8), 自由曲面鋼構造への拡 張性を有するものもあるが，その接合特性を踏まえた架構設計手法 はあまり論じられていない。設計行為や総コストに占める接合部の ウェイトが高い自由曲面鋼構造にこそ，架構と接合部を統合的に取

\footnotetext{
* 株式会社竹中工務店 工修

** 京都大学大学院工学研究科建築学専攻 准教授 · 博士 (工学)

*** 京都大学大学院工学研究科建築学専攻 教授. 工博
}

Takenaka Corporation, M. Eng.

Assoc. Prof., Dept. of Architecture and Architectural Engineering, Graduate School of Engineering, Kyoto Univ., Dr. Eng.

Prof., Dept. of Architecture and Architectural Engineering, Graduate School of Engineering, Kyoto Univ., Dr. Eng. 
り扱うことが求められるが, そのような手法は著者らの知る限り存 在しない。

本論では, 自由曲面鋼構造を対象とし，応力や变位に関する制約 条件の下で部材コストと接合コストの和を最小化する最適設計手法 を提案する。まず 2 章では, 架構形状・部材断面・接合部仕様の全 てを設計変数とする統合最適化問題を定式化する。さらに，接合剛 性は無限大(剛接合)として, 統合最適化問題を形状・断面最適化問 題(主問題) と接合コス卜最小化問題(副問題)からなる入れ子型の最 適化問題に書き換える。3 章では副問題の詳細を説明するが，ここ では高コストの全強接合と低コストの部分強度接合の 2 つの異なる 接合構法(いずれも剛接合)を想定し, 不連続なそれらのコストを近 似的に連続化する手法を示す。部分強度接合の例としては，任意の 部材取り合い角度に対応可能な, 繊維補強モルタルを用いた鉄骨接 合構法(FRM 接合, FRM: fiber reinforced mortar)を仮定する。4 章 では主問題の詳細を説明する。形状は初期形状からの修正量, 断面 は外形等の代表的寸法を設計変数とする。また, 主問題が性能の低 い局所解に陥ることを避けるため，部材コストと接合コストの重み づけを操作しながら最適解を求める手法を示寸。 5 章では例題を通 して本論で提案する手法の有効性を示す。6 章に結論を述べる。

\section{2. 最適化問題の定式化}

\section{1. 形状・断面 $\cdot$ 接合部統合最適化問題 IOPFSC}

自由曲面鋼構造においては特に, 架構形状, 部材断面および接合 部の 3 つは密接な関連を有する。例えば架構形状によって部材断面 力は大きく変わるが，断面力は部材断面や接合部を決定する際の制 約条件となるので, コストに大きな影響を与える。このことを鑑み, 上記 3 つの全てを設計変数とする統合最適化問題 IOPFSC (Integrated Optimization Problem of Forms, Sections and Connections) を定式化する。なお, 架構の応答は弾性範囲内とし, 部材応力度の検定には許容応力度設計法 9)を用いる。

\section{形状 · 断面 · 接合部統合最適化問題 IOPFSC}

設計変数の上下限值および応力・変位等に関する制約条件の下 で，部材コストと接合コストの和を最小化するような架構形状， 部材断面および接合部仕様を求めよ。

$$
\begin{array}{ll}
\text { find } & \boldsymbol{x}=\left\{\boldsymbol{x}_{f}, \boldsymbol{x}_{b}, \boldsymbol{x}_{c}\right\} \\
\text { to minimize } & P(\boldsymbol{x})=P_{f b}(\boldsymbol{x})+P_{c}(\boldsymbol{x}) \\
\text { subject to } & \boldsymbol{g}(\boldsymbol{x}) \geq \mathbf{0} \\
& \boldsymbol{h}(\boldsymbol{x})=\mathbf{0} \\
& \overline{\boldsymbol{x}}_{-l} \leq \boldsymbol{x} \leq \overline{\boldsymbol{x}}_{-}
\end{array}
$$

$\boldsymbol{x}$ は全設計変数ベクトルで, この内 $\boldsymbol{x}_{f}$ は架構形状, $\boldsymbol{x}_{b}$ は部材断 面， $\boldsymbol{x}_{c}$ は接合部を規定するべクトルである。トポロジーは予め与え られるものと寸る。 $P$ は総コストで, 部材コスト $P_{f b}$ と接合コスト $P_{c}$ の和である。 $\boldsymbol{g}, \boldsymbol{h}$ は制約関数べクトルで, 一般に架構の応答 (例 : 応力, 変位)に関寸るものや, 設計変数間の関係を規定するも の(例 : 部材せいを揃える)がある。 $\overline{\boldsymbol{x}}_{-l}, \overline{\boldsymbol{x}}_{-}$はとそれぞれ $\boldsymbol{x}$ の下限值・ 上限值ベクトルである。以下同様に, 形状および断面に関する変数
は ()$_{f b}$, 接合部に関する変数は ()$_{c}$ で表し, 設計変数の下限值・上 限值は $\overline{()}{ }_{l}, \overline{()}{ }_{u}$ で表す。

\section{2. 問題 IOPFSC の入れ子型最適化問題への書き換え}

問題 IOPFSC $の \boldsymbol{x}_{c}$ には，接合強度だけでなく接合剛性(部材端回 転剛性)を規定するパラメータを含めることができる。しかしながら， 仮に最適な接合剛性が得られても，それを実際の構造物において精 度良く実現することは困難である。そこで本論では，接合部は全て 剛接合(接合剛性が無限大) とし，ある部材端 $k$ の接合強度がベクト ル $\boldsymbol{x}_{c, k}$ によって規定されるとする。部材端の数 $(2 \times$ 部材数 $)$ を $n_{e}$ と して $\boldsymbol{x}_{c}=\left\{\boldsymbol{x}_{c, k}\right\}\left(k=1, \ldots, n_{e}\right)$ である。この場合, 架構の弾性応答は $\boldsymbol{x}_{c}$ に依存せず， $\boldsymbol{x}_{c, k_{1}}$ と $\boldsymbol{x}_{c, k_{2}}\left(k_{1} \neq k_{2}\right)$ には相関もないので, 問題

\begin{tabular}{|c|c|}
\hline given & $\tilde{\boldsymbol{x}}_{f}, \tilde{\boldsymbol{x}}_{b}$ \\
\hline find & $\boldsymbol{x}_{c, k}$ \\
\hline to minimize & $p_{c, k}\left(\tilde{\boldsymbol{x}}_{f}, \tilde{\boldsymbol{x}}_{b}, \boldsymbol{x}_{c, k}\right)$ \\
\hline subject to & $\boldsymbol{g}_{c, k}\left(\tilde{\boldsymbol{x}}_{f}, \tilde{\boldsymbol{x}}_{b}, \boldsymbol{x}_{c, k}\right) \geq \mathbf{0}$ \\
\hline & $\boldsymbol{h}_{c, k}\left(\tilde{\boldsymbol{x}}_{f}, \tilde{\boldsymbol{x}}_{b}, \boldsymbol{x}_{c, k}\right)=\mathbf{0}$ \\
\hline & $\overline{\boldsymbol{x}}_{c, k_{-} l} \leq \boldsymbol{x}_{c, k} \leq \overline{\boldsymbol{x}}_{c, k_{-} u}$ \\
\hline
\end{tabular}
IOPFSC を次のように形状・断面最適化問題 OPFS (Optimization Problem of Forms and Sections) と接合コスト最小化問題 MPCC (Minimization Problem of Cost of each Connection)からなる入れ 子型の最適化問題に書き換えることができる。

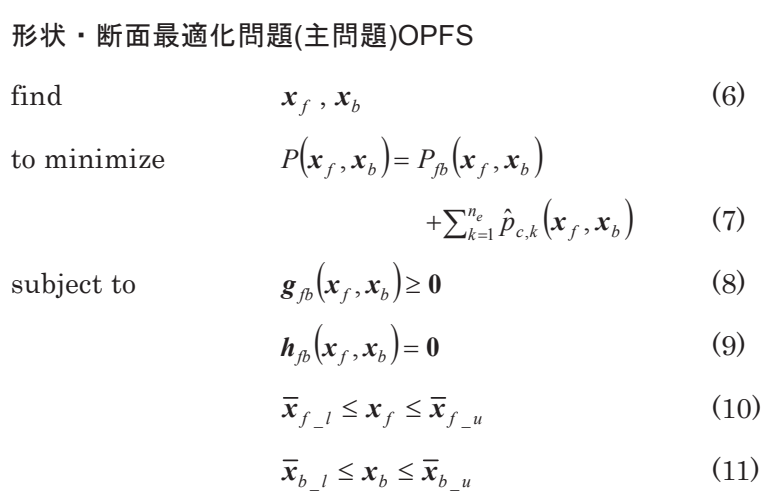

ここに $\hat{p}_{c, k}$ は部材端 $k$ の最小接合コストで, 次の接合コスト最 小化問題 MPCC で求められる。

$\boldsymbol{g}_{f b}$ と $\boldsymbol{h}_{f b}$ は架構形状および部材断面に, $\boldsymbol{g}_{c, k}$ と $\boldsymbol{h}_{c, k}$ は部材端 $k$ に関 する制約関数ベクトルである。 $p_{c, k}$ は部材端 $k$ の接合コストで, 式 (2)の接合コストは $P_{c}=\sum_{k=1}^{n_{e}} \hat{p}_{c, k}$ である。( ) は, 主問題 OPFS 全体 としては設計変数だが副問題 MPCC においては指定值として扱う 量であることを示す。

\section{3. 副問題 MPCC の設定および最適化手法}

本論では，鋳鋼ノードや切削加工ノードによる全強接合(任意角 $\mathrm{S}$ 接合)と, 繊維補強モルタルを用いた部分強度接合(FRM 接合)の 2 
種類を考える。接合剛性は共に剛接合とする。FRM 接合について は簡便な許容応力度設計式と材工単価を仮定した上で手法を展開す るが，これはあくまで部分強度接合の一例であり，本論の手法は剛 接合である限り他の接合構法にも適用可能である。

本章ではまず，想定する FRM 接合の構成の具体例を説明する。 次に, コスト特性の異なる FRM 接合と任意角 $\mathrm{S}$ 接合を連続的に取 り扱うことができるような, 副問題 MPCC の具体例とその解法を 示す。さらに, 所要接合強度(すなわち部材端断面力) と最小接合コ ストとの関係を図示した上で，主問題 OPFS の意図を補足する。

\subsection{FRM 接合の構成}

本論で仮定する FRM 接合の構成を図 1 に示寸。鉄骨部材の端部 にはエンドプレート(エンド PL)が溶接されており, エンド PLには 機械式定着部を持つスタッド鉄筋およびシアキーが溶接される。接 合ノード内部には格子鉄筋が配された上で FRM が打設される。こ の FRM 接合により，格子鉄筋の組み方や型枠を変えるだけで，任 意の角度で取り合う鉄骨部材を接合することができる。

同図(b),(c)には寸法記号を付記するが，この内入 は本論では定数 もしくは指定值である。 $\bar{L}_{c}$ はエンド PLから鉄骨材軸交点までの距 離, $\bar{d}_{y}, \bar{d}_{z}$ は鉄骨部材外形から FRM 表面までの距離, $\bar{d}_{r y}, \bar{d}_{r z}$ は FRM 表面からスタッド鉄筋芯までの距離である。( )は $\boldsymbol{x}_{f}, \boldsymbol{x}_{b}$ もし くはそれらによって定まる量だが，副問題 MPCC においては指定 值として扱う。 $\widetilde{H}$ は鉄骨部材のせい, $\widetilde{B}$ は幅である。スタッド鉄 筋比は上端筋・下端筋それぞれ $p_{r y, k}$, 腹筋片側分で $p_{r z, k}$ で, これら

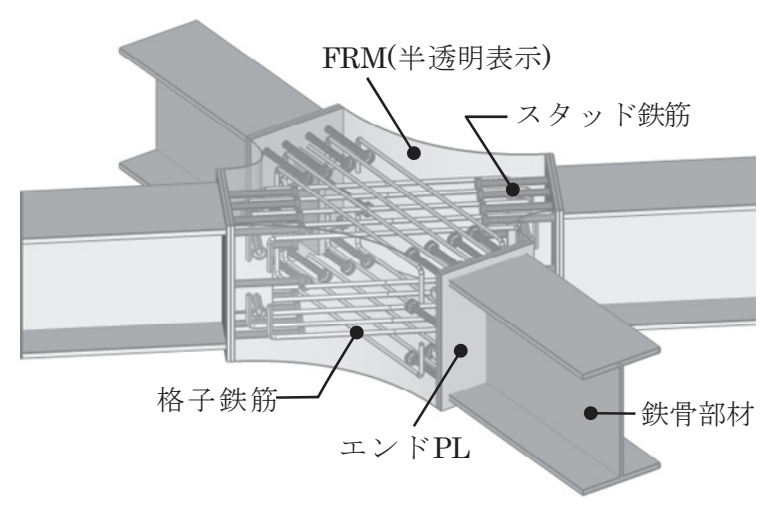

(a) 全体図

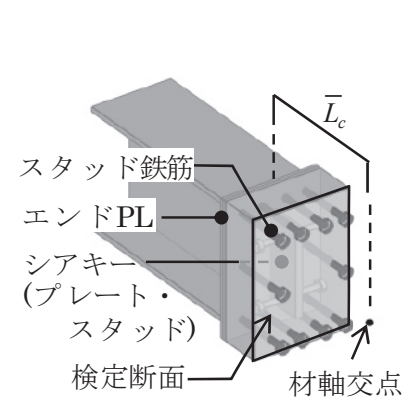

(b) 部材端

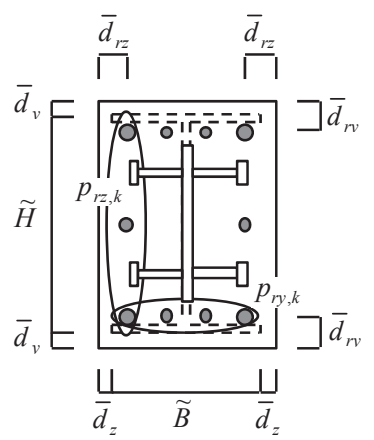

(c) 検定断面

図 1 FRM 接合の構成

は副問題 MPCC の設計変数 $\boldsymbol{x}_{c, k}$ の一部である。

FRM 接合の接合強度は様々な要因で決定されるが, 本論では現 実性を失わない範囲で問題を簡単にするため, 次のような仮定もし くは限定条件を設ける。なお，接合強度は鉄骨部材の軸方向力およ び曲げモーメントのみについて考える。せん断力は考慮しないが， 同様に採り入れることは可能である。

1)部材端の接合強度は, シアキー先端から微小量だけ材軸交点側に 入った断面(図 1(b),(c), 検定断面)における，FRM およびスタッ ド鉄筋に支配される。接合ノード内部は FRM および鉄筋格子に よって十分な強度が確保されるが，検定断面においては鉄筋格子 を考慮しない。

2)材料は全て線形弾性とし，FRM は圧縮応力だけでなく若干の引 張応力を伝達できる(許容引張応力度を設ける)。

3）例えば下端スタッド鉄筋の効果は, 同じ断面積を持つ幅 $\widetilde{B}+2\left(\bar{d}_{z}-\bar{d}_{r z}\right)$ のプレートで置換する。

4) FRM とエンド PL との界面における離間や，FRM とスタッド鉄 筋との間の付着破壊は十分小さい。短期許容耐力の範囲内では部 材端および接合ノード内部は鉄骨部材と同等以上の剛性を有する。

\section{2. 副問題 MPCC の定式化(詳細)}

FRM 材料は高性能化が進んではいるものの, 現時点では FRM 接 合を全強接合と寸ることは困難である。FRM 接合でスタッド鉄筋 を限界まで多く配しても必要な接合強度が得られない場合には，任 意角 $\mathrm{S}$ 接合を用いる。

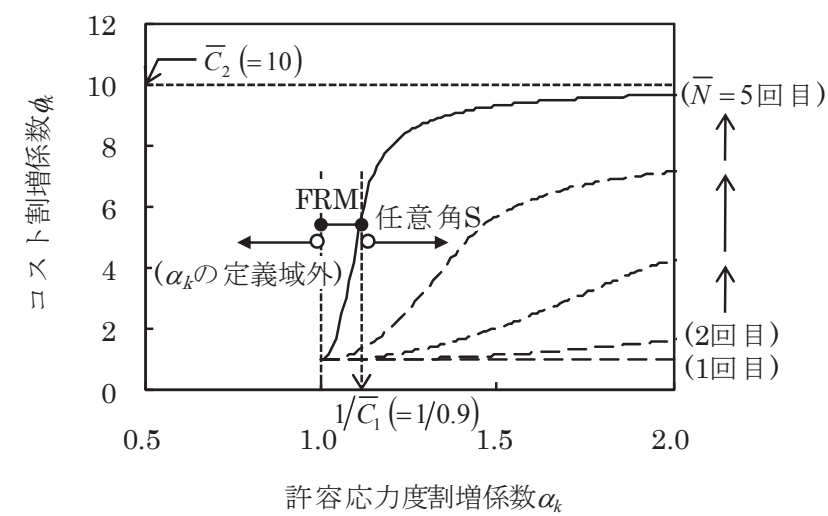

図 $2 \phi_{k}-\alpha_{k}$ 関係

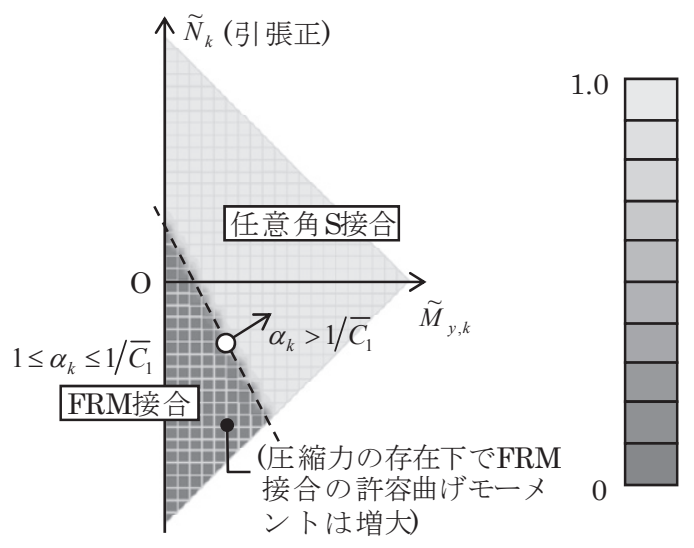

図 3 最小接合コスト曲面 
任意角 $\mathrm{S}$ 接合であれば全強接合とするのは一般に容易であり, そ のためのコスト増も殆じないので, 本論では必要強度にかかわらず 全強接合と寸る。一方, FRM 接合の接合強度はスタッド鉄筋の量(鉄 筋比)によって定まり, コストもそれに応じたものとなる。スタッド 鉄筋を上限值まで配した時のコストは任意角 $\mathrm{S}$ 接合のコストと同じ ではないため, これら 2 つの接合構法のコストは接合強度に関して 不連続となる。この不連続性は副問題 MPCC で求める最小接合コ スト $\hat{p}_{c, k}$ に現れ, 連続変数最適化問題である主問題 OPFS を解く際 に不都合を生じることが予想される。そのため, FRM 接合と任意 角 S 接合のコストを近似的に連続化することを考え, 副問題 MPCC を次のように定式化する。

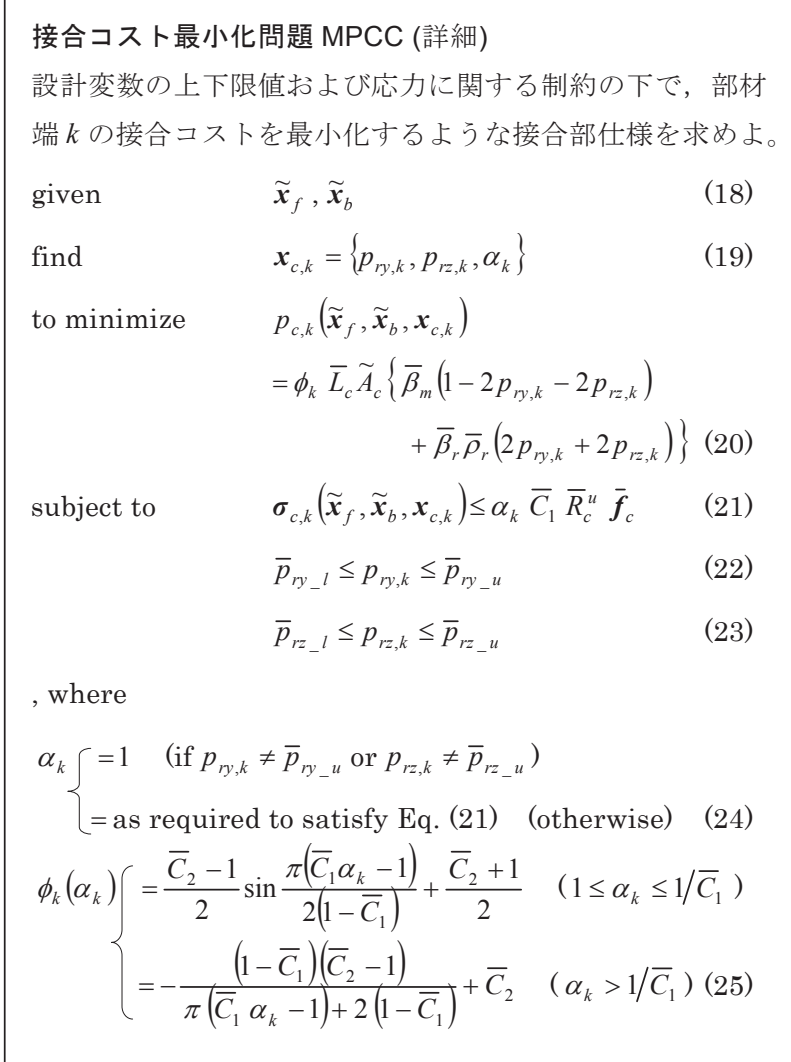

式(20)中の $\bar{\beta}_{m}$ は FRM の体積単価, $\bar{\beta}_{r}, \bar{\rho}_{r}$ はそれぞれスタッド鉄 筋の質量単価および密度である。 $\tilde{A}_{c}=\left(\widetilde{B}+2 \bar{d}_{z}\right)\left(\tilde{H}+2 \bar{d}_{y}\right)$ は部材端 $k$ の全断面積で, 簡単のためこれに $\bar{L}_{c}$ を乗じたものを部材端 $k$ にか かる体積として FRM やスタッド鉄筋の数量を算出する(図 1(b), (c) 参照)。式(21)の $\sigma_{c, k}$ は, 設計変数 $p_{r y, k}, p_{r z, k}$ および本問題では指定 值である部材端断面力 $\widetilde{\boldsymbol{F}}_{c, k}\left(\widetilde{\boldsymbol{x}}_{f}, \widetilde{\boldsymbol{x}}_{b}\right)$ や $\widetilde{H}, \widetilde{B}\left(\widetilde{\boldsymbol{x}}_{b}\right.$ の一部)によって定 まる, FRM の縁応力やスタッド鉄筋の軸方向応力である。 $\overline{\boldsymbol{f}}_{c}$ は $\boldsymbol{\sigma}_{c, k}$ の各成分に対応する許容応力度, $\bar{R}_{c}^{u}(\leq 1)$ は指定最大応力度比(応力 度比：存在応力度の許容応力度に対する比で正值)である。 $\alpha_{k}, \bar{C}_{1}$ は 後述する。 $\boldsymbol{\sigma}_{c, k}$ のある成分とそれに対応する $\overline{\boldsymbol{f}}_{c}$ の成分をそれぞれ $\sigma, \bar{f}$ として, 式(21)を式(15)に対応寸る形にすると次式となる。

$$
1-\sigma /\left(\alpha_{k} \bar{C}_{1} \bar{R}_{c}^{u} \bar{f}\right) \geq 0
$$

なお，式(16)に対応する等式制約はここでは設けない。

スカラー量 $\alpha_{k}$ は, FRM 接合と任意角 $\mathrm{S}$ 接合のコストを連続的に 扱うために導入する許容応力度割増係数で, 式(19)に示すように設
計変数の一つである。デフォルト值は $\alpha_{k}=1$ (および $\phi_{k}=1$ )だが，そ れで許容解が存在しない場合は, 式(21)が満足される最小の $\alpha_{k}$ に対 応する $\phi_{k}$ によってコストを割り増す(式(25), (20))。

式(21),(25)の $\bar{C}_{1}\left(0<\bar{C}_{1}<1\right)$ は FRM 接合と任意角 $\mathrm{S}$ 接合のコスト を連続化するために導入する仮想的な係数で, 主問題 OPFS の収束 性を確保できる範囲でできるだけ 1 に近い值に設定する。式(25)の $\bar{C}_{2}(>1)$ は任意角 $\mathrm{S}$ 接合のコストを表す係数で，スタッド鉄筋を上 限值まで配した FRM 接合のコストに対する比として, 実施例等を 参考に值を定める。図 2 の実線に $\bar{C}_{1}=0.9, \bar{C}_{2}=10$ とした場合の $\phi_{k}$ - $\alpha_{k}$ 関係を示す。破線およびその注記については後の 4.2 節で説明 する。 $\phi_{k}$ により, $1<\alpha_{k} \leq 1 / \bar{C}_{1}$ では FRM 接合のコストが大きめに, $\alpha_{k}>1 / \bar{C}_{1}$ では任意角 $\mathrm{S}$ 接合のコストが小さめに評価され, 両者が 近似的に連続化される。

副問題 MPCC は単純な最小化問題だが， $\alpha_{k}=1$ の下で許容解が 存在しない場合の扱いを規定し， $\hat{p}_{c, k}$ を $\widetilde{\boldsymbol{x}}_{f}, \tilde{\boldsymbol{x}}_{b}$ に関して連続化して いる点に特徴がある。これにより, 副問題 MPCC を連続变数最適 化問題である主問題 OPFS に取り込むことが可能となる。

\section{3. 最適化手法}

副問題 MPCC を解く手順を次に示す。

STEP 1. $\boldsymbol{x}_{c, k}=\left\{\bar{p}_{r y_{-} l}, \bar{p}_{r z_{-} l}, 1\right\}$ とし, 式(21)が満足される場合は対 応寸る $p_{c, k}$ を $\hat{p}_{c, k}$ として終了( $\mathrm{FRM}$ 接合を適用)。満足されない場 合は STEP 2 ○。

STEP 2. $\boldsymbol{x}_{c, k}=\left\{\bar{p}_{r y \_}, \bar{p}_{r z_{-} u}, 1\right\}$ とし, 式(21)が満足されない場合は 満足される最小の $\alpha_{k}$ および対応する $\phi_{k}$ を求めた上で $p_{c, k}$ を算出 し, $\hat{p}_{c, k}$ として終了 $\left(1<\alpha_{k} \leq 1 / \bar{C}_{1}\right.$ なら FRM 接合, $\alpha_{k}>1 / \bar{C}_{1}$ な ら任意角 $\mathrm{S}$ 接合を適用)。満足される場合は STEP 3 人。

STEP 3. $\alpha_{k}=1$ として最小化問題を解いて $\hat{p}_{c, k}$ を求める(FRM 接 合を適用)。

最小化問題を解くのは実質的に STEP 3 のみである。これは 2 変 数の非線形計画問題だが，条件によっては目的関数・制約関数が線 形に近くなり, 逐次 2 次計画法等では解が求められない場合がある。 一方, 主問題 OPFS を解く過程では副問題 MPCC を様々な条件下 で多数回解く必要があるので, 求解の安定性は極めて重要である。 以上を考慮し, STEP 3 では列挙法的な求解方法を用いることにす る。具体的には, 設計変数平面を格子状に分割した上で各格子点に おける目的関数值と制約関数值を計算し，制約条件を満足する格子 点の中から $p_{c, k}$ が最小となるものを特定する。そして, その近傍を さらに細かく分割することを繰り返して $\hat{p}_{c, k}$ を求める。

\section{4. 最小接合コスト曲面}

部材せい $\widetilde{H}$, 幅 $\widetilde{B}$ を与条件とすると, 部材端断面力 $\tilde{\boldsymbol{F}}_{c, k}=\left\{\tilde{N}_{k}, \tilde{M}_{y, k}, \tilde{M}_{z, k}\right\}\left(\tilde{N}_{k}\right.$ : 軸方向力(引張正), $\tilde{M}_{y, k}, \tilde{M}_{z, k}$ : 強軸, 弱軸まわり曲げモーメント)を指定すれば副問題 MPCC の最適值, すなわち最小接合コスト $\hat{p}_{c, k}$ が定まる。図 3 には, $\widetilde{H} \times \widetilde{B}=200 \times 200$ (単位は $\mathrm{mm}$ ) とした上で, $\tilde{N}_{k}$ と $\widetilde{M}_{y, k}$ を $\mathrm{H}-200 \times 200 \times 8 \times 12$ (設計基準 強度 $F=325 \mathrm{~N} / \mathrm{mm}^{2}$ )の長期許容耐力の範囲内でパラメトリックに変 化させて求めた $\hat{p}_{c, k}$ の等值線図を示す。コストは最大值を 1 として 
基準化している。ここでは $\tilde{M}_{z, k}=0$ とし, 定数・指定值は表 1 の值 を用いた。図 3 を最小接合コスト曲面と呼ぶ。 3.2 節で意図した通 り, $\alpha_{k}=1 / \bar{C}_{1}$ の前後, 寸なわち FRM 接合から任意角 $\mathrm{S}$ 接合となる 領域で $\hat{p}_{c, k}$ は急激かつ連続的に増加してほぼ一定值をとる。

図 4 には, ある $\tilde{N}_{k}(<0$, 圧縮)における最小接合コス卜曲面の切断 面を示す。同図にはあわせて, $\widetilde{H} \times \widetilde{B}=340 \times 250$ として求めたもの も示す。図中の(1)からわかるように, ある $\widetilde{\boldsymbol{F}}_{c, k}$ に対し, $\widetilde{H}, \widetilde{B}$ (すな わち部材断面 $\tilde{\boldsymbol{x}}_{b}$ の一部)を大きくすると $\hat{p}_{c, k}$ を低減できる場合があ る。ただしこの場合, 部材コストは増加する。また, 架構形状 $\tilde{\boldsymbol{x}}_{f}$ に よって $\widetilde{\boldsymbol{F}}_{c, k}$ は変化するので, (2)のように $\widetilde{H}, \widetilde{B}$ を変えずに $\hat{p}_{c, k}$ を低 減できる場合もある。架構形状および部材断面は部材コストだけで なく最小接合コストにも影響を与えることがわかるが，このことを 踏まえて総コストを最小化する $\boldsymbol{x}_{f}, \boldsymbol{x}_{b}$ を求めるのが主問題 OPFS である。

\section{4. 主問題 OPFS の設定および最適化手法}

\section{1. 主問題 OPFS の設定}

1) 設計変数 $\boldsymbol{x}_{f}, \boldsymbol{x}_{b}$

通常, 建築設計者からある自由曲面に厳密に合致する架構形状(節 点座標)を求められることは稀である。多くの場合は, 曲面のイメー

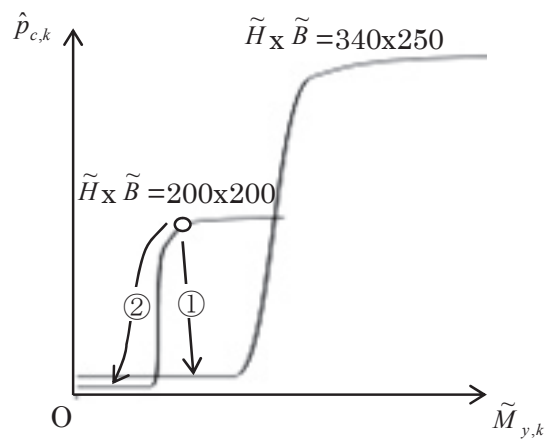

図 4 最小接合コスト曲面のある $\widetilde{N}_{k}(<0)$ における切断面

表 1 副問題 MPCC の定数・指定値

\begin{tabular}{|c|c|c|}
\hline 種類 & 名称, 記号 & 值 \\
\hline $\begin{array}{l}\text { 図 } 1 \text { 内の } \\
\text { 寸法(mm) }\end{array}$ & $\begin{array}{l}\bar{L}_{c} \\
\bar{d}_{y} \\
\bar{d}_{z} \\
\bar{d}_{r y} \\
\bar{d}_{r z}\end{array}$ & $\begin{array}{r}350 \mathrm{~mm} \\
20 \mathrm{~mm} \\
20 \mathrm{~mm} \\
40 \mathrm{~mm} \\
40 \mathrm{~mm}\end{array}$ \\
\hline 弾性定数 & $\begin{array}{c}\text { FRM } \\
\text { スタッド鉄筋 } \\
\end{array}$ & $\begin{array}{l}4.70 \times 10^{4} \mathrm{~N} / \mathrm{mm}^{2} \\
2.05 \times 10^{5} \mathrm{~N} / \mathrm{mm}^{2}\end{array}$ \\
\hline $\begin{array}{l}\text { 長期(短期) } \\
\text { 許容応力度 }\end{array}$ & \begin{tabular}{cc}
\multirow{2}{*}{ FRM } & 圧縮 \\
& 引張 \\
& スタッド鉄筋 \\
& 引縮 \\
& 引張 \\
\end{tabular} & $\begin{array}{r}60(120) \mathrm{N} / \mathrm{mm}^{2} \\
5(10) \mathrm{N} / \mathrm{mm}^{2} \\
200(295) \mathrm{N} / \mathrm{mm}^{2}\end{array}$ \\
\hline $\begin{array}{c}\text { スタッド鉄筋比 } \\
\text { 上限-下限 }\end{array}$ & $\begin{array}{c}\text { 上下端筋 } \bar{p}_{r y_{-} l}-\bar{p}_{r y_{-} u} \\
\quad \text { 腹筋 } \bar{p}_{r z}-\bar{p}_{r z} u \\
\end{array}$ & $\begin{array}{c}0.4-1.0 \% \\
0-1.0 \% \\
\end{array}$ \\
\hline 材工単価 & $\begin{array}{c}\text { FRM } \\
\text { スタッド鉄筋 } \\
\end{array}$ & $\begin{array}{l}0.15 \mathrm{MY}^{*} / \mathrm{m}^{3} \\
0.50 \mathrm{MY} * / \text { ton } \\
\end{array}$ \\
\hline その他 & $\begin{array}{c}\text { 指定最大応力度比 } \bar{R}_{c}^{u} \\
\text { 係数 } \bar{C}_{1} \\
\text { 係数 } \bar{C}_{2} \\
\end{array}$ & $\begin{array}{c}1.0 \\
0.90 \\
10 \\
\end{array}$ \\
\hline
\end{tabular}

ジを保持し建築計画上の制約を満足する範囲内であれば形状の修正 が許容される。本論では全節点座標ベクトル $z\left(\boldsymbol{x}_{f}\right)$ を, 予め与えら れる初期形状 $\overline{\boldsymbol{z}}_{o}$ および $n_{f}$ 個の形状修正モード $\overline{\boldsymbol{z}}_{j}\left(j=1, \ldots, n_{f}\right)$ の線 形和で表し， $\bar{z}_{j}$ の倍率を設計変数 $x_{f, j}$ とする。つまり, $\boldsymbol{x}_{f}=\left\{x_{f, j}\right\}\left(j=1, \ldots, n_{f}\right)$ である。 $\overline{\boldsymbol{z}}_{j}$ は基準化された定べクトルで, 建築設計者の意向や曲面の平滑性等を勘案して定める。

$$
\boldsymbol{z}\left(\boldsymbol{x}_{f}\right)=\overline{\boldsymbol{z}}_{\boldsymbol{o}}+\sum_{j=1}^{n_{f}} x_{f, j} \overline{\boldsymbol{z}}_{j}
$$

部材は $n_{S}$ 個のグループに分類され, グループ内の部材は同一断面 を採るとする。グループ $i$ に属する部材番号の集合を $S_{i}\left(i=1, \ldots, n_{S}\right)$ とする。部材断面を表寸設計変数は $\boldsymbol{x}_{b}=\left\{\boldsymbol{x}_{b, i}\right\}\left(i=1, \ldots, n_{S}\right)$ で, ベク トル $\boldsymbol{x}_{b, i}$ は $S_{i}$ の断面の代表寸法である。その他の断面寸法は, 規格 断面リストを基にあらかじめ定める寸法比を用いて従属的に定める。 例えば H 形鋼で規格断面リストに JIS G 319210)の汎用品を用いる 場合, $\boldsymbol{x}_{b, i}=\left\{H_{i}, B_{i}\right\}\left(H_{i}\right.$ : せい, $B_{i}:$ 幅 $)$ とし, ウェブ厚 $t_{1 i} \cdot$ フラ ンジ厚 $t_{2 i}$ を次の寸法比(規格断面リストにおける当該寸法比の平均 值)を用いて定める 11 。

$$
B_{i} / t_{1 i}=22.5, B_{i} / t_{2 i}=14.5
$$

\section{2) 制約条件 $\boldsymbol{g}_{f b}, \boldsymbol{h}_{f b}$}

式(8)の $\boldsymbol{g}_{f b}$ では, 部材の応力に関する制約を設ける。各部材 $j \in S_{i}$ の全荷重ケースにおける応力度比の最大值を $r_{j}\left(\boldsymbol{x}_{f}, \boldsymbol{x}_{b}\right)$ とし, これ を指定最大值 $\bar{R}_{i}^{u}(\leq 1)$ 以下とする。

$$
1-r_{j}\left(\boldsymbol{x}_{f}, \boldsymbol{x}_{b}\right) / \bar{R}_{i}^{u} \geq 0
$$

この他, 部材断面の外形寸法に関寸る制約 $1-B_{i} / H_{i} \geq 0$ や幅厚比制 約を設ける。また，式(9)の $\boldsymbol{h}_{f b}$ では異なるグループ間の断面寸法に 関する制約(例：異なる $i$ について $H_{i}$ を同一とする)を考慮する。

\section{3) 目的関数 $P$}

目的関数は総コスト $P$ で, 部材コスト $P_{f b}$ と接合コスト $P_{c}=\sum_{k=1}^{n_{e}} \hat{p}_{c, k}$ の和である。この内 $P_{f b}$ は, グループ $i$ の部材の総質量 を $M_{i}$, 質量単価を $\bar{\beta}_{i}$ として次式で表す。

$$
P_{f b}\left(\boldsymbol{x}_{f}, \boldsymbol{x}_{b}\right)=\sum_{i=1}^{n_{S}} \bar{\beta}_{i} M_{i}\left(\boldsymbol{x}_{f}, \boldsymbol{x}_{b, i}\right)
$$

$P_{c}$ に含まれる $\hat{p}_{c, k}$ は, 各部材端 $k$ について求める副問題 MPCC の 目的関数の最適值である $(3$ 章参照 $)$ 。

\section{2 最適化手法}

主問題 OPFS の最適化手法には逐次 2 次計画法 12),13) 老用いる。 目的関数や制約関数の感度係数は差分法を用いて近似的に計算する。 これにより, 応力度比 $r_{j}$ や最小接合コスト $\hat{p}_{c, k}$ に内在する感度係数 の不連続性は疑似的に解消される。

主問題 OPFS にはしばしば性能の大きく異なる局所解が存在し, 初期解によっては性能の低い(総コストの高い)方に収束してしまう。 局所解には大きく分けて次の 2 種類があるが, これは概して, 部材 断面を大きくすると部材コストは増加するが FRM 接合が適用可能 となる部材端が増えて接合コストは減少することに起因する。

解 A. 部材コストは小さく抑えられているが，多くの部材端は任意 角 $\mathrm{S}$ 接合の $\alpha_{k}$ が大きい領域にある $\left(\phi_{k}\right.$ がほぼ $\bar{C}_{2}$ に収束している) ような解である。この場合, 微小量だけ部材断面を大きくすると, 部材コストは増加するが接合コストは減少しても僅かなので, 総 
コストとしては増加となる。一方, 部材断面を小さくすると応力 度比制約が満足されなくなるので，局所解と認識される。

解 B. 幾つかの部材端が FRM 接合の適用可能範囲の限界に近い領 域にある解である。この場合，微小量だけ部材断面を小さくする と, 部材コストは減少するが上記部材端が任意角 $\mathrm{S}$ 接合となって 接合コストが大幅に増加し, 総コストとしては増加となる。一方, 部材断面を大きくすると部材コストは増加する上に, 元々 FRM 接 合である接合コストは減少しないので, 総コストとして増加とな り，局所解と認識される。

解 $\mathrm{A}, \mathrm{B}$ のどちらの性能が高いかは対象とする架構の条件による ので, 性能の高い方に収束するような初期解をあらかじめ定めるこ とは難しい。複数の初期解に対して最適化を実行し, 最も性能の高 い解を見出すことは可能だが，初期解の選定は試行錯誤となってし まう。また, そもそも 2 種類の解が別個に存在せず, 多くの初期解 を試行しても性能の低い局所解を回避できたのか判断できない場合 もある。そこで本論では, 初期解は 1 つとしたまま次の 2 つの方法 で主問題 OPFS を解いて性能の高い解を選択する。

解法 $A$ (解 $A$ を指向). 任意角 $S$ 接合のコストを意図的に小さく評価 して解を求め, 徐々に本来の設定值に近づける。つまり, 部材コ スト $P_{f b}$ に関する定数(式(31)の $\bar{\beta}_{i}$ ) は最初から設定值を維持した まま, 接合コスト $P_{c}=\sum_{k=1}^{n_{e}} \hat{p}_{c, k}$ に関する定数 (式 $(21),(25)$ の $\left.\bar{C}_{1}, \bar{C}_{2}\right)$ を小さい值から段階的に設定值に近づける。より具体的に は, $\bar{C}_{1}$ を $\Delta \bar{C}_{1}=\bar{C}_{1} / \bar{N}$ 刻みで $\Delta \bar{C}_{1}$ から, $\bar{C}_{2}$ を $\Delta \bar{C}_{2}=\left(\bar{C}_{2}-1\right) / \bar{N}$ 刻 みで $1+\Delta \bar{C}_{2}$ から設定值に近づけながら, 主問題 OPFS を指定回 数 $\bar{N}$ 回だけ解く。2 回目以降の最適化の初期解にはその前の回の 最適解を用いる。 $\bar{C}_{1}=0.90, \bar{C}_{2}=10, \bar{N}=5$ とした場合の $\phi_{k}$ の推移 を図 2 の破線およびその注記で示す。

解法 B (解 B を指向). 逆に, 部材コスト $P_{f b}$ を小さく評価して解を求 めることから始める。つまり， $\bar{C}_{1}, \bar{C}_{2}$ は最初から設定值に固定し たまま, $\bar{\beta}_{i}$ を $\Delta \bar{\beta}_{i}=\bar{\beta}_{i} / \bar{N}$ 刻みで $\Delta \bar{\beta}_{i}$ から段階的に設定值に近づ けながら, 主問題 OPFS を $\bar{N}$ 回解く。

解法 $\mathrm{A}, \mathrm{B}$ のいずれかで大域的最適解が得られる保証はないが，2 つの対照的なアプローチを採ることで性能の低い局所解を回避でき る可能性は格段に高まる。なお, 合計 $2 \bar{N}$ 回も最適化問題を解くこ とになるが，複数の制約条件がアクティブとなる許容空間の隅角部 に最適解があり, 解が初期段階での収束值から移動しない(つまり, その後の最適化では最適性条件の確認だけで済むことが多いので, あまり問題とはならない。また, 解法 $\mathrm{A}, \mathrm{B}$ では求解経路が大きく異 なるので, 解は一つだが感度係数の不連続性や目的関数曲面の複雑 さが原因で収束が得難い場合でも，どちらか一方は収束する可能性 が高まる。

\section{3. 単純例題: 圧縮カと曲げモーメントを受ける柱}

図 5 に示寸柱を用いて, 前節の解法 A, B の具体例を示す。柱は 設計基準強度 $F=325 \mathrm{~N} / \mathrm{mm}^{2}$ の $\mathrm{H}$ 形鋼で, 部材断面を $\boldsymbol{x}_{b}=\left\{\boldsymbol{x}_{b, 1}\right\}=\left\{H_{1}, B_{1}\right\}$ とする。ウェブ厚, フランジ厚は式(28),(29)の 寸法比で定める。質量単価は $\bar{\beta}_{1}=0.15 \mathrm{MY} / \mathrm{ton}$, 指定最大応力度比は
$\bar{R}_{1}^{u}=0.9$ とする。副問題 MPCC の設定 は， 3.2 節および表 1 の通りとする。

図 6(a)に, $H_{1}, B_{1}$ をパラメトリック に変化させて作成した部材コスト $P_{f b}$ の等值線図および制約条件を示す。コ スト值は後述の総コスト $P$ の最大值 を 1 として基準化している。 $P_{f b}$ は図 中の点 a で最小值をとるが, 解法 $\mathrm{A}$ は 任意角 $\mathrm{S}$ 接合のコストを意図的に小さ く評価した最適化から始まるので，そ の初期段階では点 $\mathrm{a}$ の近傍に収束する。

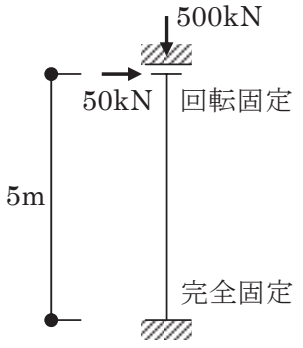

図 5 柱モデル 同様に, 図 6(b)には接合コスト $P_{c}$ の等

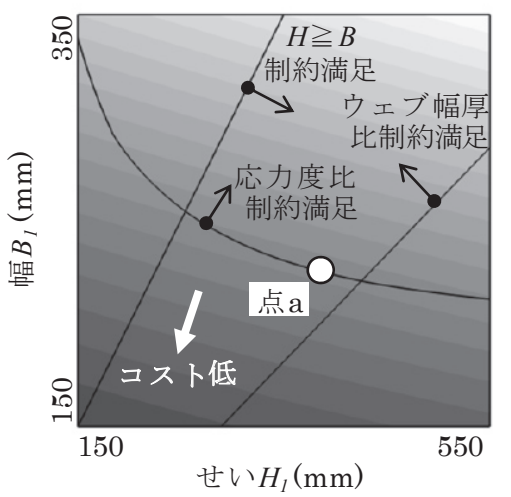

0.29

(a) 部材コスト $P_{f b}$ のみ

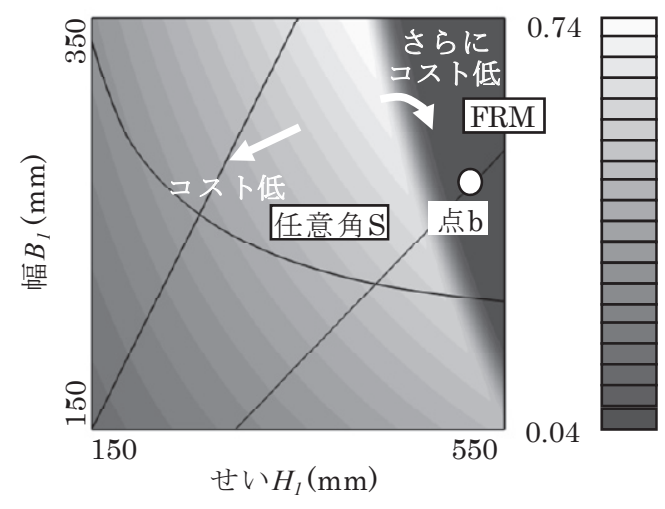

(b) 接合コスト $P_{c}$ のみ

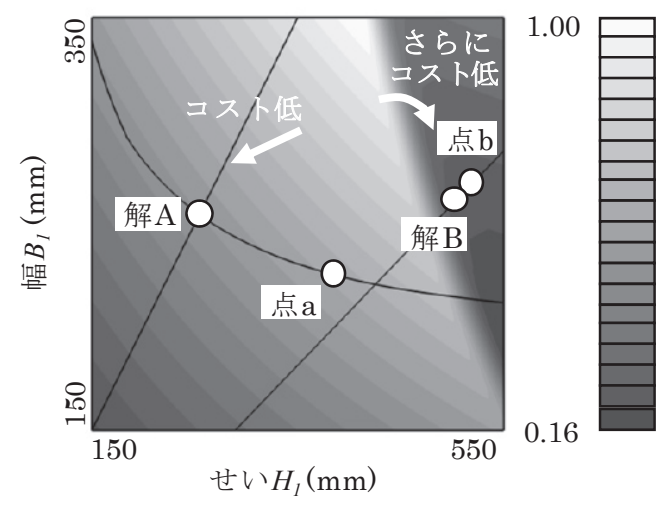

(c) 総コスト $P=P_{f b}+P_{c}$

図 6 コスト等值線図 
值線図を示す。点 b で最小值をとるが, 解法 B は部材コストを小さ く評価した最適化から始まるので, 初期段階では点 $\mathrm{b}$ の近傍に収束 する。同図(c)は総コスト $P$, 寸なわち主問題 OPFS の目的関数の等 值線図である。 $P$ には 2 つ局所解 $\mathrm{A}, \mathrm{B}$ があり, どちらに収束す るかは通常は初期解に依存するが, 解法 A では概して点 $\mathrm{a}$ 近傍から

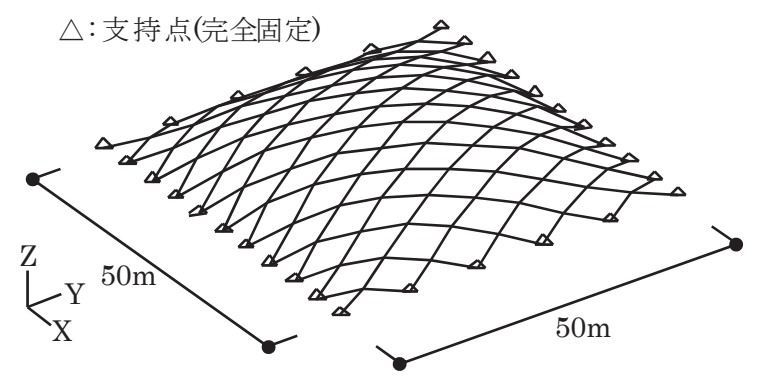

(a) 鳥瞰図

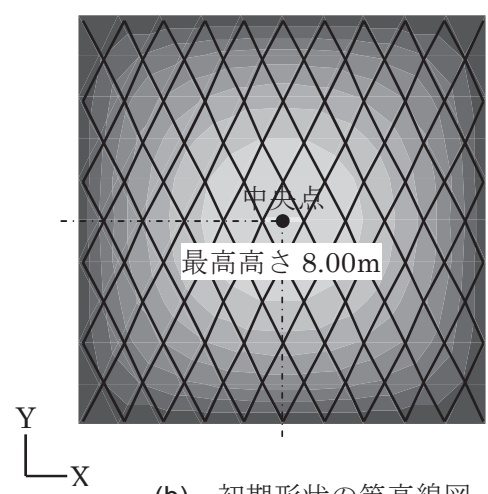

(b) 初期形状の等高線図

図 7 自由曲面架構

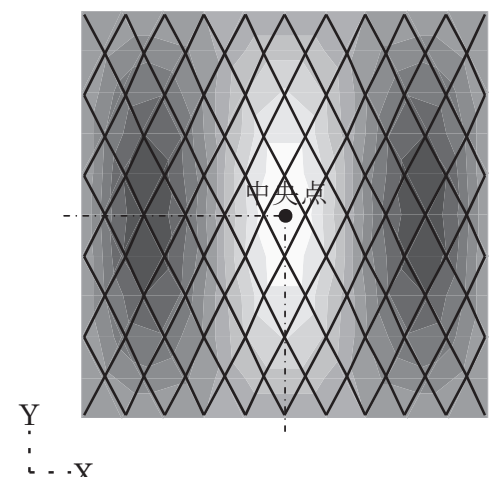

(a) モード $j=1$

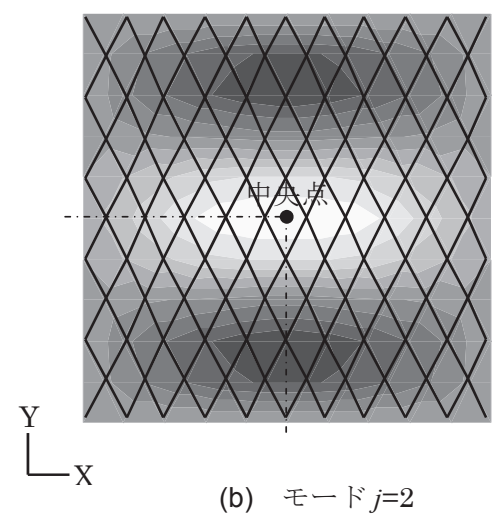

図 8 形状修正モード $\overline{\boldsymbol{z}}_{j}$
解 $\mathrm{A}$ 一, 解法 $\mathrm{B}$ では点 $\mathrm{b}$ 近傍から解 $\mathrm{B}$ への収束を得ることができ る。つまり，基本的に初期解を試行錯誤で探索することなく両方の 解を得ることができるので，そこから性能の高い方(本例では解 B) を選択寸ればよい。なお，本例では $\bar{N}=5$ としたので最適化を 10 回実行しているが, 求解中に解が移動した(実質的に最適化計算を実 行した)のは計 5 回に留まっている。

\section{5. 例題}

図 7 の自由曲面架構を考える。架構は四辺形グリッドで構成され た平面形 $50 \mathrm{~m} \times 50 \mathrm{~m}$ の単層ラチス屋根で, 初期形状は高さ $8 \mathrm{~m}$ の等 張力曲面である。節点数は 126 , 部材数は 200 である。部材は設計 基準強度 $F=325 \mathrm{~N} / \mathrm{mm}^{2}$ の $\mathrm{H}$ 形鋼で, 許容応力度の算定においては 節点間距離を個材の座屈長さとする。各節点には鉄骨質量および屋 根表面積 $1 \mathrm{~m}^{2}$ あたり $160 \mathrm{~kg}$ に相当する集中質量が配置されている。 なお，本論では架構形状および部材断面は設計変数なので，上記の 集中質量は従属変数となる。鉛直下向き荷重を $D=1.0 \mathrm{~g}(\mathrm{~g}$ :重力加 速度), $\mathrm{X}, \mathrm{Y}$ 方向の地震荷重をそれぞれ $E_{x}, E_{y}=0.4 g$ とし, $D$ を長 期荷重ケース， $D \pm E_{x}, D \pm E_{y}$ を短期荷重ケースとして作用させる (荷重ケース数は 5 )。外周の節点は完全固定とし，そこに接続する部 材端のコストも接合コストに算入する。

形状修正モード数は $n_{f}=2$ とし, 式(27)の形状修正モード $\bar{z}_{j}(j=1,2)$ は図 8 の等值線図に示す通りとする。架構形状を規定す る設計変数は各モードの倍率 $\boldsymbol{x}_{f}=\left\{x_{f, 1}, x_{f, 2}\right\}$ である。部材グループ 数は $n_{S}=1$ とし，部材断面を表す設計変数を $\boldsymbol{x}_{b}=\left\{\boldsymbol{x}_{b, 1}\right\}=\left\{H_{1}, B_{1}\right\}$ と する。ウェブ厚, フランジ厚は式(28),(29)の寸法比で定める。質量 単価は $\bar{\beta}_{1}=0.15 \mathrm{MY} / \mathrm{ton}$, 指定最大応力度比は $\bar{R}_{1}^{u}=0.9$ とする。副問 題 MPCC に関する設定は，3.2 節および表 1 の通りとする。

設計変数や接合コストの扱いが異なる 4 つのースについて最適 化を実行した結果を表 2 に示す。以下では，それぞれの解について より詳細に説明しながら，本論の提案手法の有効性を示す。

なお，本論の提案手法は自由曲面鋼構造の構造設計において検討 すべき項目全てを網羅するものではなく，制約条件には，許容応力 度設計等の一般性の高い項目のみを採り入れている。従って，実際 の構造設計では，塑性領域も含めた全体座屈耐力や，短期許容耐力 超過後の接合剛性の低下がそれに与える影響等について, 別途確認

表 2 最適化ケースと結果まとめ

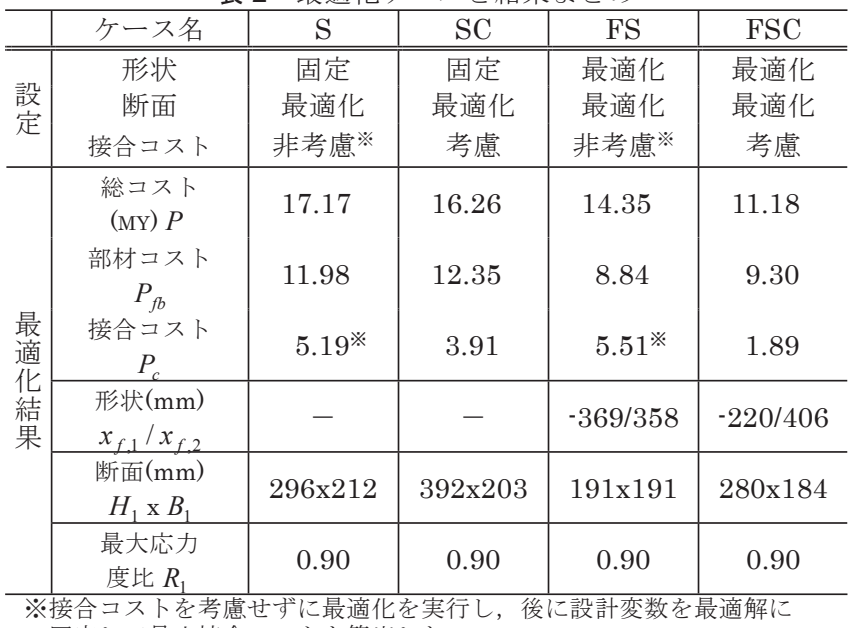

固定して最小接合コストを算出した。 
する必要がある。全体座屈耐力が不足する場合は， $\bar{R}_{i}^{u}$ を低い值に 設定し直して再度最適化を実行する等の措置が必要となる。全体座 屈耐力を何らかの形で制約条件に採り入れることも考えられるが例 えば14), 本論では行わず今後の課題とする。また, 本例題は提案手法 の有効性を端的に示すために実施するもので，荷重等の設定は簡略 なものとしている。例えば地震荷重は, 本来は予備応答解析を実施 して, 水平入力に対する上下応答等も考慮しつつ設定す心゙きである が，例題では簡便に水平方向 $0.4 \mathrm{~g}$ としている。また，支持点の剛性 は, 本来は支持構造の剛性を評価して設定すべきだが, 例題では完 全固定としている。

\section{1. ケース S: 断面最適化}

ケース $\mathrm{S}$ は, 部材コストのみを目的関数とした断面最適化である (既往手法もしくはその組合せ)。架構形状は図 7 の初期形状のまま である。最適断面は H-296x212(x9.5x14.6), 総コストは $17.17 \mathrm{MY}$ となった(表 2 参照)。この内 $5.19 \mathrm{MY}$ が接合コストだが，これは断面 を最適断面に固定して副問題 MPCC を解いて求めたものであり, 断面最適化中には考慮していない。図 9(a)に各部材 $j$ の最適解にお ける応力度比(全荷重ケース中の最大值） $r_{j}$ の分布を示す。図中の線 幅は応力度比の值に比例している。全部材中の最大值 $R_{1}=\max _{j \in S_{1}}\left\{r_{j}\right\}$ は指定最大值 $\bar{R}_{1}^{u}(=0.9)$ に達しているものの, 多くの 部材には咒長性が残されている。同図(b)には部材端接合形式を示す。 固定支持された外周部は曲げモーメントが大きく, 高コストの任意 角 $\mathrm{S}$ 接合が適用される結果となっている。なお, 同図中の*印を付 記した節点において FRM 接合と任意角 $\mathrm{S}$ 接合が混在する接合ノー

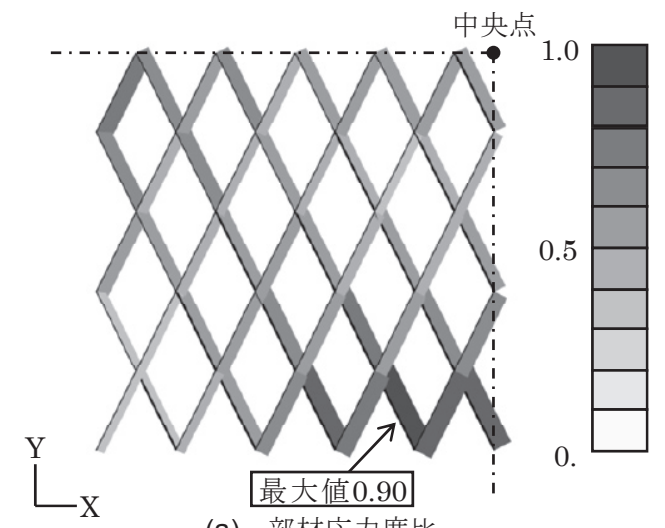

(a) 部材応力度比

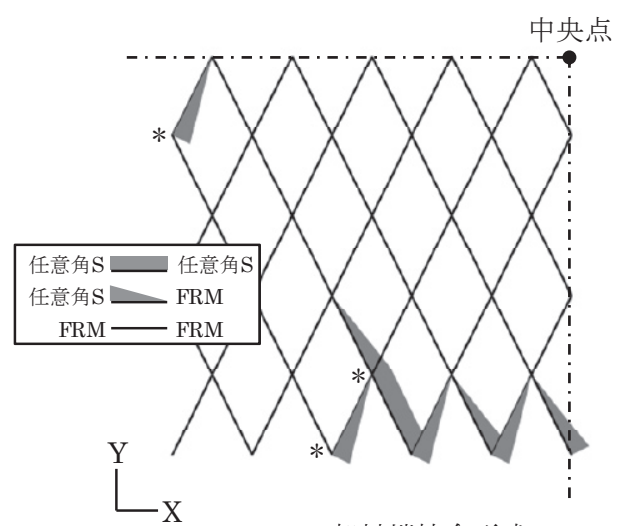

(b) 部材端接合形式

図 9 ケース $\mathrm{S}$ の最適解
ドを構成することは可能だが，全部材端を任意角 $\mathrm{S}$ 接合とした方が 低コストとなる場合もある。特に任意角 $\mathrm{S}$ 接合として鋳鋼を用いる 場合は混在させない方が良い。そのような検討および判断は，個々 の建物に応じて構造設計者が行う必要がある。

\section{2. ケース SC: 接合コストを考慮した断面最適化}

ケース SC は，部材コストに加えて接合コストも考慮した断面最 適化である。最適断面はケース $\mathrm{S}$ よりせい $H_{1}$ が大きく, 幅 $B_{1}$ が若 干小さい H-392x203(x9.1x14.0) となった(部材コストは $3.1 \%$ 増)。 図 10(a)に応力度比の分布を示寸が, 最大值は $R_{1}=0.90$ で $\bar{R}_{1}^{u}$ に達し ている。同図(b)には部材端接合形式を示す。低コストの FRM 接合 が適用可能な部位がケース S に比して増加し, 接合コストは $25 \%$ 減 少している。つまり, 本ケースでは, 部材断面を大きくして FRM 接合の接合強度上限值を上げ，その適用可能部位を増やすことで， 総コストを低減(ケース $\mathrm{S}$ に比して 5.3\%減)寸る解が求められている。

以上のことをより直感的に把握するため, $\boldsymbol{x}_{b}=\left\{H_{1}, B_{1}\right\}$ をパラメ トリックに変化させて作成した総コスト $P$ の等值線図を図 11 に示 す。コスト值は表示範囲における最大值が 1 となるように基準化し ている。同図にはあわせて制約条件(応力度比制約, ウェブ幅厚比制 約)を示す。点 $\mathrm{a}$ は部材コストの最小点, 点 $\mathrm{b}$ は接合コストの最小点 である。点 a から $H_{1}$ を大きくし， $B_{1}$ を制約条件が満足される範囲 で小さく寸ることが $P$ の低減に繋がることがわかる。なお，本ケー スでは局所解は存在しないので, 4.2 節の解法 A, B のいずれも同一 の解に到達するはずだが, 解 $\mathrm{A}$ と解 $\mathrm{B}$ は異なるものとなった。より 性能が高いのは解 A である。解法 B でも解 A に接近はするものの,

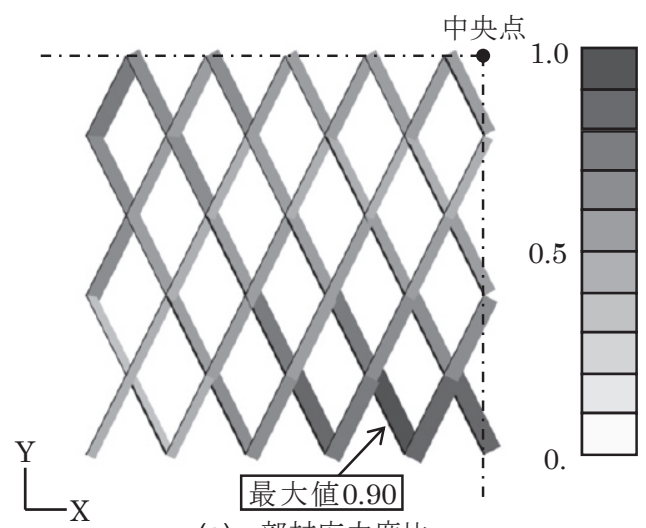

(a) 部材応力度比

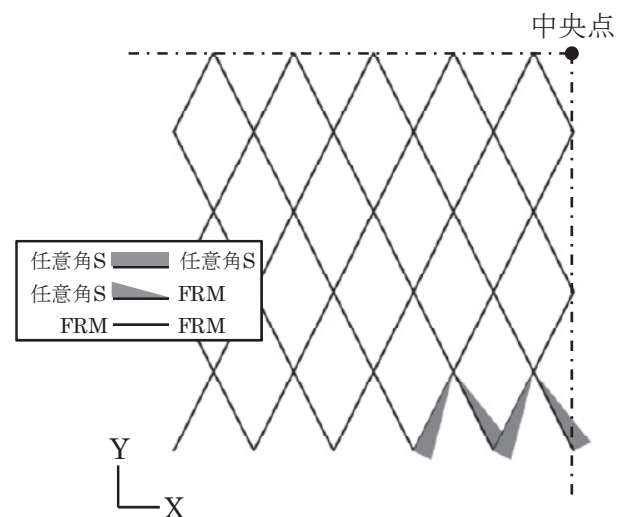

(b) 部材端接合形式

図 10 ケース $\mathrm{SC}$ の最適解 
接合コストが急増する際の感度係数の急変に起因して収束性に問題 が生じ, 解 B に留まっている。 2 つ大きく異なる求解経路をとる ことで, 求解の安定性が高められていると言える。

本例題では, 任意角 $\mathrm{S}$ 接合の FRM 接合に対するコスト比を表す 係数 $\bar{C}_{2}(>1)$ を 10 と設定している(3.2 節および表 1 参照)。これは ある実物件を参考に与えたものだが，物件によって異なる場合があ るので, ここでは $\bar{C}_{2}$ が目的関数(総コスト)の最適值に与える影響を 調べる。また，両接合構法のコストを連続化するために導入した仮 想的な係数 $\bar{C}_{1}\left(0<\bar{C}_{1}<1\right)$ についても同様に調べる。表 3 に, 複数 の $\left(\bar{C}_{1}, \bar{C}_{2}\right)$ の組に対して最適化を実行して得た総コストを, $\left(\bar{C}_{1}, \bar{C}_{2}\right)=(0.90,10)$ の場合を 1 として基準化した值を示す。 $\left(\bar{C}_{1}, \bar{C}_{2}\right)$ の 影響は小さいことがわかるが，これは本論の最適化では概して低コ ストの FRM 接合の適用部位が多い解が得られるため, 任意角 $\mathrm{S}$ 接 合のコストが総コストに占める割合が小さくなることに起因してい る。なお, $\bar{C}_{2}=15$ では, $\bar{C}_{1}=0.85,0.90$ の場合と $\bar{C}_{1}=0.95$ の場合と で任意角 $\mathrm{S}$ 接合の数に大きな差があり, 最適解の特性が異なる。主 問題 OPFS の収束性が確保されるのであれば $\bar{C}_{1}$ は 1 に近い值とし た方が本来の不連続なコスト特性をより忠実に表現できるので, こ の場合は $\bar{C}_{1}=0.95$ を用いるべきだが, 収束性や最適解の性状は前も って知ることはできない。 $\bar{C}_{1}$ は, 若干の試行錯誤を行った上で設定 する必要がある。

\section{3. ケース FS: 形状・断面最適化}

ケース FS は, 架構形状と部材断面の両方を設計変数とし, 部材 コストのみを目的関数とした最適化である(既往手法もしくはその 組合せ)。最適形状の等高線図を図 12(a)に示すが，初期形状(図 7)

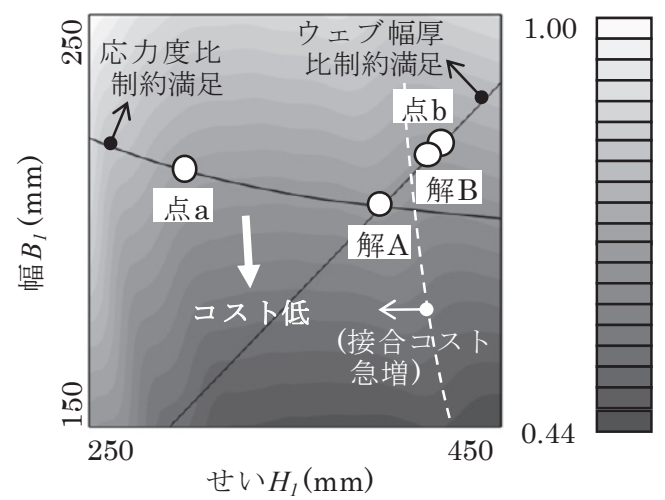

図 11 総コスト $P$ の等値線図

表 3 総コストの最適值(基準化)と係数 $\bar{C}_{1}, \bar{C}_{2}$ の関係

\begin{tabular}{c|c|c|c|c}
\hline \multicolumn{2}{c|}{} & \multicolumn{3}{|c}{$\bar{C}_{1}$} \\
\cline { 3 - 5 } \multicolumn{2}{c|}{} & 0.85 & 0.90 & 0.95 \\
\hline \hline \multirow{6}{*}{5} & 0.95 & 0.94 & 0.94 \\
& \multirow{4}{*}{$\bar{C}_{2}$} & $=0.74+$ & $=0.74+$ & $=0.74+$ \\
& & $0.20[20]$ & $0.20[20]$ & $0.20[20]$ \\
\cline { 3 - 5 } & \multirow{4}{*}{10} & 1.00 & 1.00 & 1.00 \\
& & $=0.76+$ & $=0.76+$ & $=0.75+$ \\
& & $0.24[16]$ & $0.24[16]$ & $0.25[16]$ \\
\cline { 2 - 5 } & \multirow{3}{*}{15} & 1.03 & 1.04 & 1.04 \\
& $=0.76+$ & $=0.76+$ & $=0.86+$ \\
& & $0.27[16]$ & $0.28[16]$ & $0.18[0]$ \\
\hline
\end{tabular}

※各欄の数值は基準化された総コスト=部材コスト+接合コストを表す。

[ ] は任意角 S 接合となった部材端の数を示す(部材端総数は 400)。
に比して僅かに頂部が高く, 中腹部では X 方向に膨らみ, $\mathrm{Y}$ 方向に 縮んだ形状となっている。最適断面はケース $\mathrm{S}$ より大幅に小さい H-191x191(x8.5x13.2) となり, 部材コストは 26\%低減している。図 12 (b) に応力度比の分布を示寸が, 平均值 0.69 (標淮偏差 0.11 ) と高值 に分布しており，断面性能が効率的に利用されている。通常，部材 コストの低減にはライズの修正が効果的だが，中腹部の膨らみを僅 かに操作するだけで大きな効果が得られている。一方，接合コス卜 はケース S に比して $6.2 \%$ 増加している。これは, 架構形状を修正 して最小断面を追求した結果，FRM 接合の接合強度上限值が低下 し,任意角 $\mathrm{S}$ 接合が必要な部位が増加したことによる(図 $12(\mathrm{c}$ )参照)。

\section{4. ケース FSC: 接合コストを考慮した形状・断面最適化}

ケース FSC は, 架構形状と部材断面の両方を設計変数とし, 部 材コストと接合コストの和を目的関数とした最適化である。最適形

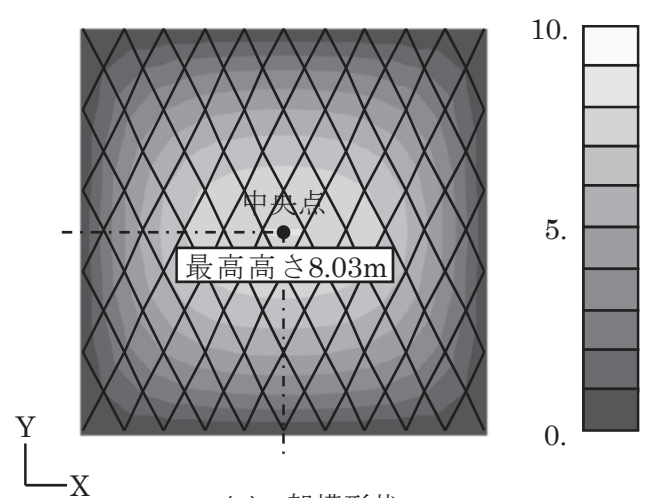

(a) 架構形状

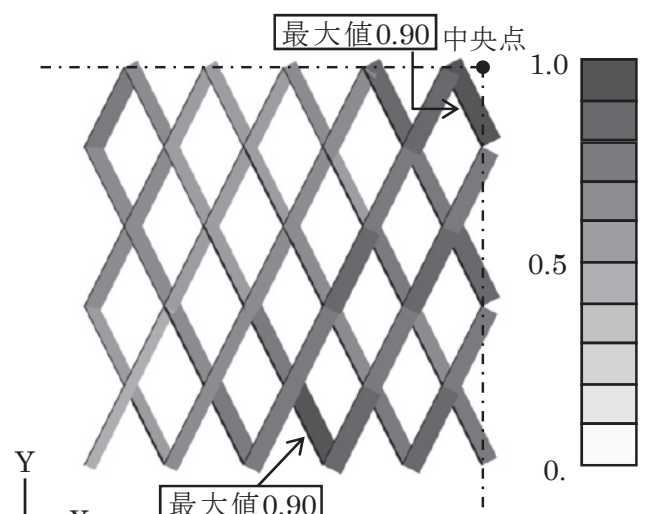

(b) 部材応力度比

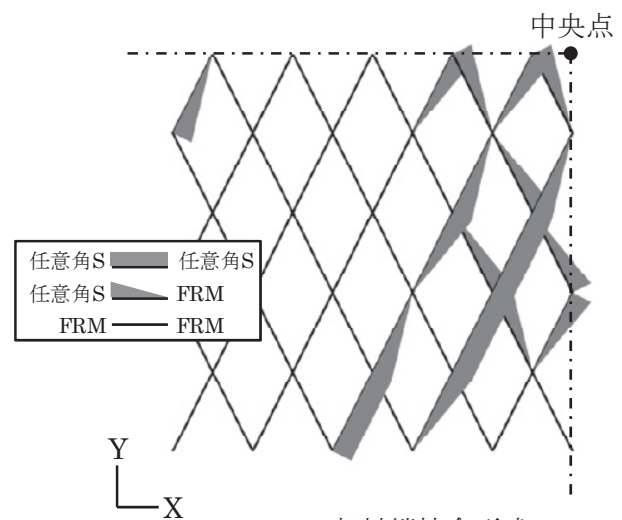

(c) 部材端接合形式

図 12 ケース FS の最適解 

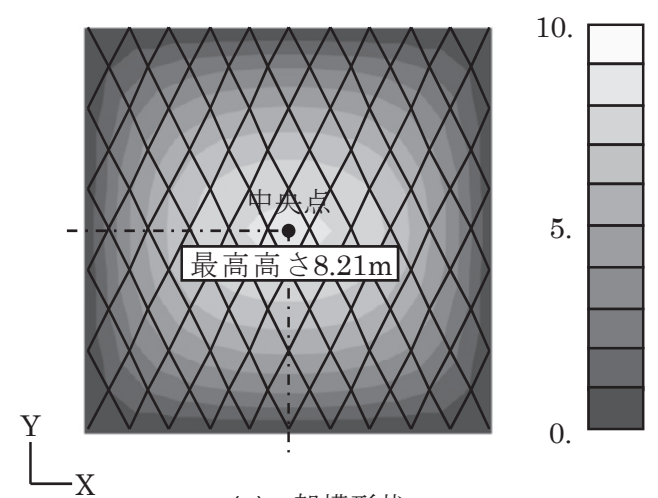

(a) 架構形状

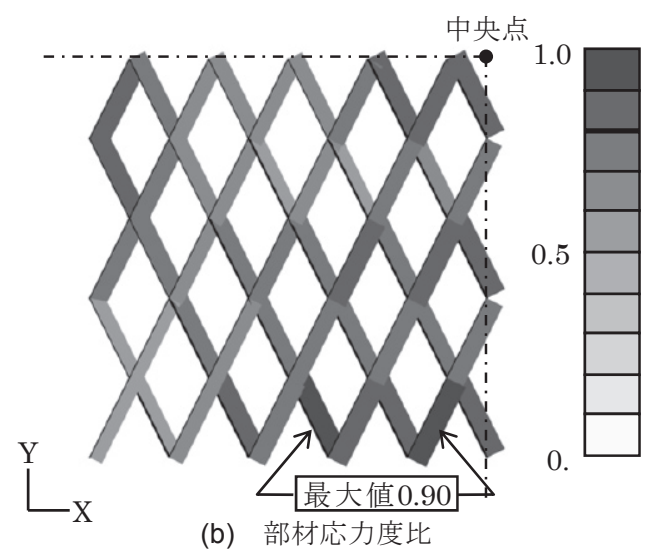

図 13 ケース FSC の最適解

状の等高線図を図 13(a)に示す。ケース FS(図 12(a)) と同様の傾向を 示しているが, 頂部は $181 \mathrm{~mm}$ 高くなっている。最適断面はケース FS よりせいが大きく, 幅が若干小さい $\mathrm{H}-280 \mathrm{x} 184(\mathrm{x} 8.2 \mathrm{x} 12.7)$ とな った(部材コストは $5.2 \%$ 増)。これら最適解は解法 A で得られた。図 13(b)に応力度比の分布を示寸が, 全体的に高值を維持している。部 材端接合形式は全て FRM 接合となった。接合コストはケース FS の $66 \%$ 減，ケース SC と比べても $52 \%$ 減となっている。総コストは 11.18MY で，全ケースの中で抜きん出て小さい。本論で提案する, 架構(形状, 部材断面) と接合部を統合的に取り扱うことの効果が明 確に現れている。なお, 部材断面を最適解にせい・幅が近い JIS 規 格断面である H-294x200x8x12 に変えた場合, 総コストは $11.56 \mathrm{MY}$ (=部材コスト $9.54 \mathrm{MY}+$ 接合コスト $2.02 \mathrm{MY}$, 部材端は全て FRM 接合) となる。

\section{6. 結論}

本論では，接合コストを考慮した自由曲面鋼構造の最適設計問題 について, 次の結論を得た。

1) 接合剛性を剛とした上で, 形状・断面最適化問題 (主問題) と接合 コスト最小化問題 (副問題) からなる入れ子型の最適化問題を定式 化した。主問題の目的関数は部材コストと最小接合コストの和で, 最小接合コストは各部材端について副問題を解くことで得られる。 これにより,部材コストと接合コストの和が最小となる架構形状, 部材断面および接合部仕様を求めることができる。

2) 副問題において, 仮想的な許容応力度割増係数およびその関数で あるコスト割増係数を導入し, 部分強度接合を規定する諸量を用
いたまま全強接合のコストを近似的に表現する手法を示した。こ れにより，特性の異なる 2 つの接合構法のコストを連続的に取り 扱うことができる。

3)主問題において，部材コストもしくは接合コストの重みを段階的 に操作しながら最適化を繰り返す手法を提案した。この 2 種類の 最適化を実行することで, 初期解を試行錯誤で探索することなく, 性能の低い局所解を回避することができる。また,この手法には, 局所解は存在しないが接合コストの感度係数の急变に起因して解 の収束性が悪い場合において, より安定的に最適解を得る効果が あることを例証した。

4) 単層ラチス架構の例題を通して, 本論で提案した手法の有效性を 示した。部材コストに加えて接合コストを目的関数に含めること， および，部材断面だけでなく架構形状も設計変数とすることで， いずれかを採り入れない解に比して総コストを大幅に低減する設 計解が得られた。

\section{参考文献}

1) 大崎純 : 遺伝的アルゴリズムに基づく不連続コスト関数を有する構造物の 最適設計法, 日本建築学会構造系論文集 第 464 号, pp. 119-127，1994.10 2) 松本慎也，春日康博，藤井大地，藤谷義信：接合部のコストを考慮した半 剛接鉄骨建物の最小コスト解析, 日本建築学会構造系論文集 第 528 号, pp. 113-119，2000.2

3) 清水斉，澤田樹一郎，松尾彰，佐々木尊一，安井孝，南波篤志：鉄骨製作 コストを考慮した鉄骨骨組の最小コスト設計 その 1 鉄骨製作コスト評 価式の提案, 日本建築学会大会学術講演梗概集, B-1, pp. 233-234, 2006 4)佐々木尊一，清水斉，澤田樹一郎，松尾彰：鉄骨製作コス卜を考慮した鉄 骨骨組の最小コスト設計 その 2 最小重量設計と最小コスト設計の比較, 日本建築学会大会学術講演梗概集, B-1, pp. 235-236, 2006

5) 金子佳生，三橋博三，桐越一紀，阿部孝仁:鋼繊維補強セメント系複合材料 の新分野一の適用 一鋼構造柱梁接合法に関する基礎実験一, 日本建築学 会技術報告集 第 14 号，pp.119-122，2001.12

6) 梁一承, 西山功, 白井一義, 上田宣人: 高勒性セメント複合材料を用いた鉄 骨間柱の中央部接合に関する研究，コンクリート工学年次論文集 Vol. 26 No. 2, pp. 1261-1266, 2004

7) 西山功, 梁一承, 福山洋, 諏訪田晴彦: 高勒性セメント複合材料を用いた鉄 骨ブレースの中央部接合に関する研究，コンクリート工学年次論文集 Vol. 26 No. 2, pp. 1267-1272, 2004

8) 長谷川嘉子, 金久保利之, 飯干福馬, 白井一義, 米丸啓介: 超高強度繊維補 強コンクリートを用いた複層立体トラスの開発，日本建築学会技術報告集 第 14 巻第 28 号, pp. 459-464，2008. 10

9) 日本建築学会 : 鋼構造設計規準 一許容応力度設計法一, 2005 10）日本規格協会：JIS ハンドブック 2009 (2)鉄鋼 II , pp. 544-545，2009 11) 藤井英二, 荒木慶一, 上谷宏二 : グルーピング過程を含む鋼構造物の対話 型部材断面決定法, 日本建築学会構造系論文集 第 664 号, pp. 1161-1169, 2011.6

12) Spellucci, P.: An SQP method for general nonlinear programs using only equality constrained subproblems, Mathematical Programming 82, pp.413-448, 1998.

13) Spellucci, P.: A new technique for inconsistent problems in the SQP method, Mathematical Methods of Operations Research 47, pp.355-400, 1998.

14) 小河利行, 大崎純，立石理恵: 線形座屈荷重最大化と部材長一様化を目的 とした単層ラチスシェルの形状最適化, 日本建築学会構造系論文集 第 570 号, pp. 129-136, 2003.8

（2011年 4 月 9 日原稿受理，2011年 8 月26日採用決定） 